\title{
Abundance and Habitat Preference of the Genus Euplectes in Protected and Non- protected Habitats of Jos East Plateau State, Nigeria
}

\section{${ }^{* 1}$ FRANCIS, MJ; ${ }^{2}$ CHASKDA, AA; ${ }^{3}$ OMBUGADU, A; ${ }^{4}$ KARAU, SD; ${ }^{1}$ MATHIAS, OC; ${ }^{5}$ OLORI-OKE, O; ${ }^{6}$ YAKUBU, CK}

\author{
${ }^{* 1}$ Department of Forestry Technology, Federal College of Forestry Jos, P.M.B. 2019, Jos, Plateau State, Nigeria. \\ ${ }^{2}$ A.P. Leventis Ornithological Research Institute, P.O Box1344, Department of Zoology University of Jos, Nigeria. \\ ${ }^{3}$ Department of Zoology, Faculty of Science, Federal University of Lafia, P.M.B. 146, Lafia, Nasarawa State, Nigeria \\ 4. National Centre for Remote Sensing Jos Plateau State Nigeria. \\ ${ }^{5}$ Department of Pest Management Technology, Federal College of Forestry Jos, P.M.B. 2019, Jos, Plateau State, Nigeria. \\ ${ }^{6}$ Department of Horticulture and Landscape Technology, Federal College of Forestry Jos, P.M.B. 2019, Jos, Plateau State, Nigeria. \\ *Corresponding Author: Email: mundi_francis@yahoo.com \\ Other Author Email: mundi-francis@yahoo.com; chaskdaa@unijos.edu.ng, chaskda@yahoo.com; akwash24@gmail.com; \\ shomborokarau@gmail.com talk2nev@yahoo.com; oge1winner1@gmail.com; adrom835@fcfjos.edu.ng; cristyshaibu19@gmail.com
}

\begin{abstract}
The knowledge on the factors influencing habitat selection is of uttermost importance because it guides the development of conservation action plan for species. Till date, there is no baseline study on the genus Euplectes in Northern Nigeria thus, an attempt to investigate the habitat preference of the genus was carried out in Amurum Forest Reserve and the nonprotected habitats of Fobur. Line transects of $200 \mathrm{~m}$ were randomly laid across the study sites. The abundance of Bishop species was highest in farmland compared to grassland and rocky outcrop. Therefore, the number of the species was significantly different between habitats $\left(\mathrm{F}_{2,573}=5.454, \mathrm{P}=0.0015\right)$. There was a significant relationship between flock size and number of seeds across habitat types. Number of individual birds increased with increase in seed number $\left(\mathrm{F}_{1,57}=21687.786, \mathrm{P}<0.001\right)$. With the exception of grass height, there was a highly significant difference in relation to vegetation variables taken between plots where Bishop species were sighted and the random points where they were not seen $(\mathrm{P}<0.001)$. The finding suggests that farmlands should be integrated into conservation plan in the nonprotected area based on the high population of the genus recorded.
\end{abstract}

DOI: https://dx.doi.org/10.4314/jasem.v25i8.7

Copyright: Copyright $($ 2021 Francis et al. This is an open access article distributed under the Creative Commons Attribution License (CCL), which permits unrestricted use, distribution, and reproduction in any medium, provided the original work is properly cited.

Dates: Received: 10 May 2021; Revised: 28 June 2021; Accepted: 01 July 2021

Keywords: Habitat selection, Genus Euplectes, Protected and nonprotected habitats, Vegetation variables

The genus Euplectes are predominantly Afrotropical group of birds and are primarily seed-eating species (Fry and Keith, 2004). They include the Northern red Bishop Euplectes franciscanus, Black-winged red Bishop Euplectes hordeaceus and Yellow-mantled widow Bird Euplectes macroura. During breeding season, males are easily differentiated from females while there is no sexual dimorphism during nonbreeding season (Borrow and Demey, 2013). Understanding the factors underlying habitat selection is very crucial in both ecological and evolutionary contexts which is crucial for developing conservation action plan for species (Pasinelli et al., 2016). Urbanization has become a dominant geographical trend and a very important aspect of global change whose effect is a serious threat to biodiversity (Clergeau et al., 2001; Munoz-Pedreros et al., 2018). This accounts for loss of vegetation especially in areas considered to be nonprotected and thereby displacing species that might have selected such habitats because of the habitat variables present. There is therefore a correlation between bird abundance, diversity, richness and density with vegetation variables depending on the guild (Chettri et al., 2005). Studies are few in Africa on the impact of degraded habitats such as farmlands and other nonprotected areas on bird communities (Hulme, 2007). Therefor e, the study on the habitat preference of the genus Euplectes in protected and nonprotected habitats of Jos East Plateau State was carried out.

\section{MATERIALS AND METHODS}

Study Area: This research was carried out in Amurum Forest Reserve in Laminga and Fobur both in Jos East Local Government on the Jos Plateau. The Jos Plateau is located within the Guinea Savanna region of Nigeria. It is located in central Nigeria $\left(09^{0} 52^{\prime} \mathrm{N}, 08^{0}\right.$ $58^{\prime} \mathrm{E}$ ) with a land mass above $1000 \mathrm{~m}$ (Hulme, 2007). 
Jos east is located in the North east of Plateau State and the vegetation of the area is typical of that of the Jos plateau as a whole which is mainly a scattered bush and grass, with Rocky outcrops and fragments of Riparian Forest with its bushes cleared for farming and for fuel wood (Hulme, 2007). The Amurum Forest Reserve is located $15 \mathrm{~km}$ Northeast of Jos and is a small area, covering up to $300 \mathrm{~h}$ which is a repository of significant biological diversity especially the avian species which include two formerly acclaimed endemic species - the Rock firefinch (Lagonosticta sanguinodorsalis) and the Plateau indigo bird (Vidua maryae). The Reserve lies on the coordinate $09^{0} 53^{\prime} \mathrm{N}$ $08^{0} 59^{\prime} \mathrm{E}$. Fobur on the other hand lies on the coordinate $09^{\circ} 52.0^{\prime} \mathrm{N}, 09^{\circ} 2.0^{\prime} \mathrm{E}$ and has its bushes degraded by human activities mainly, farming, logging and grazing.

Data collection: A total of 250 transects each of approximately $200 \mathrm{~m}$ were randomly laid per site which was used to record the Bishops (Bibby et al., 2000; Yallop et al., 2003). The transects were $100 \mathrm{~m}$ apart. The survey was done daily between 7:00am and 10:00am and 4:00-6:00pm. A pair of binoculars (Trekka, magnification 10×42) and field guide of birds of Western Africa were used for bird identification (Borrow and Demey, 2004). Number seen was then estimated per transect. The research was conducted during the non-breeding season of the study species.

Vegetation measurement: Number of trees and tree height, number of shrubs and shrub height were measured within $10 \mathrm{~m}^{2}$ plot as adopted from Manu and Cresswell, (2007); Atuo and Manu, (2013). The trees were considered of height $>2 \mathrm{~m}$ while shrubs were of height $<2 \mathrm{~m}$. We randomly selected four $2 \mathrm{~m}^{2}$ quadrats within the $10 \mathrm{~m}^{2}$ by throwing a stick over the shoulder (Manu and Cresswell, 2007; Atuo and Manu, 2013) and the following vegetation variables were estimated by eye: percentage ground cover (to the nearest 5\%), percentage leaf litter (to the nearest 5\%) and percentage bare ground (to the nearest 5\%) (Manu, 2002). Also, number of grasses and average height were measured. Shrub and grass height were measured using a marked ranging pole which is then measured using a measuring tape calibrated in centimeters and meters. The plots are areas within the transects where Bishops were seen and the coordinates of those locations were marked using a GPS (Figure 1). There were also randomly selected vegetation plots $40 \mathrm{~m}$ away from the foraging plots used as control areas which were compared to areas where bishops were seen.

Estimating seed availability: Within sixty $10 \mathrm{~m} \times 10 \mathrm{~m}$ plots where Bishop Species were sighted, a $2 \mathrm{~m}$ x $2 \mathrm{~m}$ quadrat was marked and seed reserves scooped from soil of $1 \mathrm{~cm}$ deep were collected in polythene bags and germinated via watering for two weeks and the germinating seedlings in each polythene bag was counted similar to Atuo and Manu (2013) but because our species flock in larger group during this season, a larger soil, about 400 times was scooped.

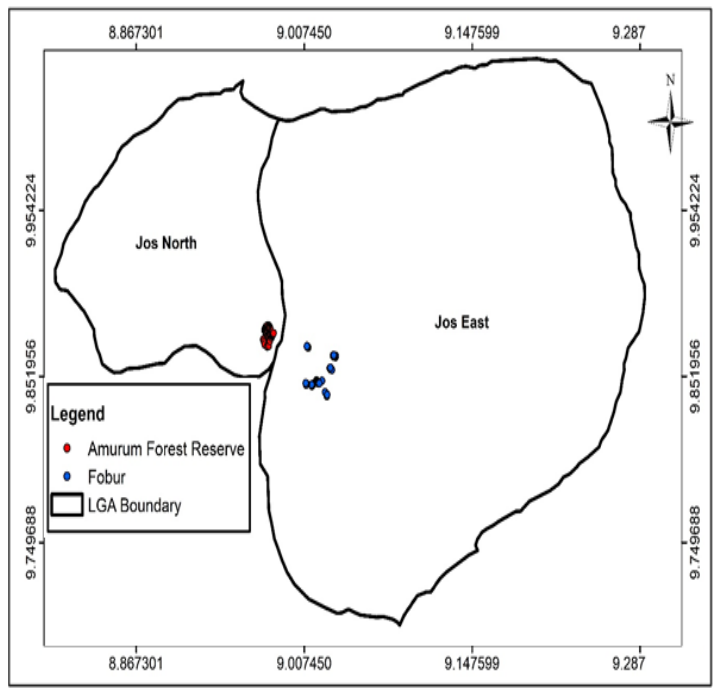

Fig 1: map of the study area showing plots

Statistical analysis: R-console software (version 3.2.2) was used. Student t-test was carried out to determine the mean abundance of Bishops in the two sites. Spearman's rank correlation was used to test the relationship between vegetation variables in order to choose the variables to be included in the model. A generalized linear model (GLM) was done to check habitat variables influencing bishop abundance. A paired sample t-test was used for the comparison of Bishop habitats with the random sites. One-Way Analysis of Variance (ANOVA) was carried out to check Bishop species numbers in different habitat types. Linear regression was used to test the influence of seed availability on flock size. $P$ values $<0.05$ were considered statistically significant.

\section{RESULTS AND DISCUSSION}

The overall number of bishop species seen was highest in farmland followed by grassland and least in rocky outcrop. Therefore, the number of the species was significantly different between habitat types $\left(\mathrm{F}_{2,573}=\right.$ 5.454, $\mathrm{P}=0.0015)$. In Fobur, there was significantly more Bishops in farmlands compared to savannah grassland whereas in Amurum Forest Reserve, there was significantly more Bishops in savannah grassland compared to the rocky outcrop. The Northern red Bishops had the highest abundance in farmland compared to the Black-winged red Bishops while 
Yellow-mantled widowbirds were not recorded in farmlands during this study.

Relationship between vegetation variables of bishop plots and standard points: There was a highly significant difference between number of trees, number of shrubs and shrub height, number of grass, percentage ground cover, percentage leaf litter and percentage bare ground between the plots and standard points. However, there was no significant difference between grass height of the Bishop's habitat and the random point (Table 1). The number of Bishops significantly increased with increase in percentage bare ground across all habitat types and the abundance significantly decreased with increase in number of trees across all the habitats while the number of shrubs, shrub height as well as number of grass showed no significant influence on Bishops abundance.

Table 1: Mean vegetation differences between sites and random points

\begin{tabular}{|c|c|c|c|c|}
\hline & Paired variables & $\mathrm{T}$ & Df & $\mathrm{P}$ \\
\hline Pair 1 & Number of trees and random number of trees & -19.7167 & 579 & $<0.001^{*}$ \\
\hline Pair 2 & Number of shrubs and random number of shrubs & -5.8903 & 578 & $<0.001^{*}$ \\
\hline Pair 3 & Shrub height (m) and random shrub height (m) & -5.6952 & 579 & $<0.001 *$ \\
\hline Pair 4 & Number of grass and random number of grass & 5.3038 & 579 & $<0.001 *$ \\
\hline Pair 5 & Grass height $(\mathrm{m})$ and random grass height $(\mathrm{m})$ & 0.2236 & 579 & $0.82^{\text {ns }}$ \\
\hline Pair 6 & $\%$ Ground cover and random $\%$ ground cover & -5.8193 & 579 & $<0.001 *$ \\
\hline Pair 7 & $\%$ Leaf litter and random \% leaf litter & -15.2653 & 579 & $<0.001^{*}$ \\
\hline Pair 8 & $\%$ Bare ground and random $\%$ bare ground & 12.6339 & 579 & $<0.001 *$ \\
\hline
\end{tabular}

Effect of Seed number on flock size: There was a significant relationship between flock size and number of seeds in the three habitat types. Number of individual birds seen increased with increase in seed number $\left(\mathrm{F}_{157}=21687.786, \mathrm{P}<0.001\right.$, Figure 2$)$.

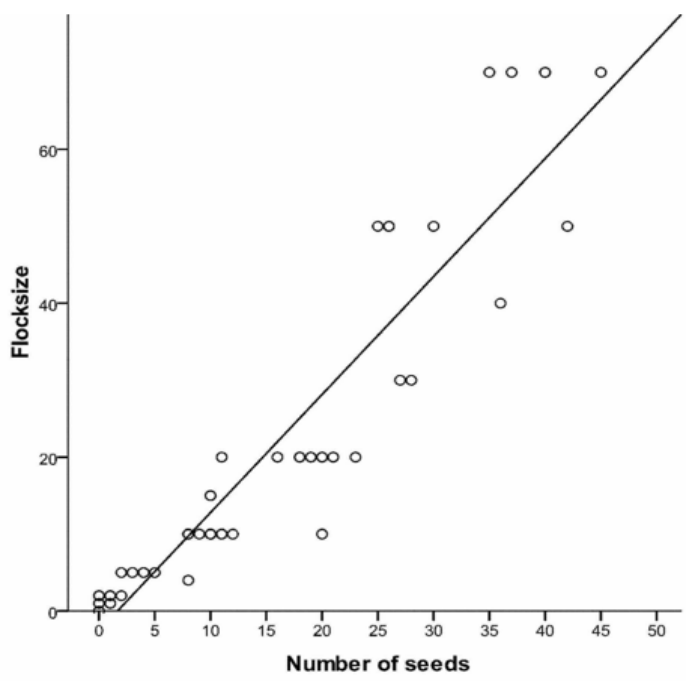

Fig 1: The association between flock size and seed abundance

Variation in number seen between sites: Bishops abundance differed significantly between the two sites $(t=-3.29, d f=578, p<0.05$, Figure 3$)$. Bishop species were mostly encountered in the non-protected site than in the Forest Reserve which can be explained by detectability in open areas. This however does not necessarily mean that bird density in areas with bushes or trees have low density but were probably not visible during the study. The farmlands had the highest abundance probably due to seed availability during this survey. It is in accordance with Akogwu et al.,
(2012) who also recorded high abundance of granivores in the surrounding farms of Assop Forest Reserve in Jos, Plateau state compared to other habitats and linked it largely to availability of grains and seeds and the ability of the birds to utilize disturbed habitats to expand their home ranges.

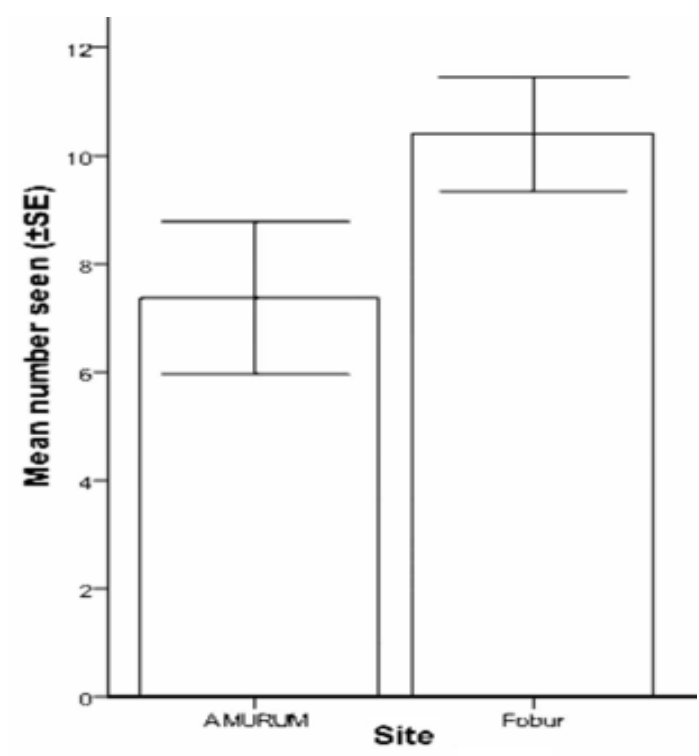

Fig. 3: Mean abundance of bishops seen in relation to the two study sites

This also agrees with Soderstrom et al., (2003) where generalist species were successful in human disturbed habitats but not of any conservation concern. This finding is similar to Mahiga et al., (2019) on the influence of land-use type on forest bird community composition in Mount Kenya Forest where granivore bird species were more in farmlands than any other feeding guild which was attributed to food resources 
in such habitat. The Bishops in Amrum Forest Reserve were mostly recorded in the savannah grassland. Habitat choice in the Northern red Bishop was probably driven mostly by seed availability because of the abundance of cereals and sedges available in such habitats (Fry and Keith, 2004). They were often observed on ground and concentrated at sites with grasses in the Reserve and in the surrounding farmlands. Yellow-mantled widowbird were observed once on the rocky-outcrop very close to moist grassland near a pool of water on the rock. Their number was more in grassland, but such habitats were always moist. The Northern red Bishop and the Blackwinged red Bishop both showed a preference for farmland, with a high abundance of the sedge Coleochloa abyssinica, Andropogon species, Digitaria exilis and Penisetum species showing that food availability is one major limiting factor for a number of species on farmland (Hulme, 2007). The number of the three Bishop species recorded in farmlands and savanna grassland showed a positive correlation with the number of seeds. This is in accordance with the ideal free distribution theory (Cody, 1985) which states that foraging patches are characterized by intrinsic quality which corresponds to a patch's exploitation rate when the density of consumers approaches zero. Vegetation variables varied strongly between Bishops' habitats and the control areas. In the Reserve, the birds prefer the grassland savanna and the surrounding farmlands where mean percentage ground cover $=20.49 \% \pm 0.6$, $\mathrm{N}=580$ ) and a mean grass height $=0.8 \mathrm{~m} \pm 0.02, \mathrm{~N}=$ 580 or areas completely bare similar to Atuo \& Manu (2013) on the territory size and habitat selection of Cinnamon-breasted Rock Bunting Emberiza tahapisi in Amrum Forest Reserve and surrounding farmlands where vegetation variables of the species taken within territories differed significantly from randomly selected unoccupied locations. The three Bishop species showed a significant trend towards selection of habitat patches with relatively low percentage bush or ground cover and high percentage bare ground. Hence, the height of surrounding vegetation could affect the ability of the bird to locate seeds on the ground. It has been documented that it is easier to locate seeds on bare soil than on short or tall grass substrates (Soderstrom et al., 2003) and this probably explains the relationships between bare patches and abundance of the three Bishop species. The Bishops were significantly higher in the unprotected site compared with the protected Forest. This agrees with the findings of Asefa et al., (2017) on effects of anthropogenic disturbance on the diversity of birds in Ethiopia where mean abundance was higher in unprotected Forest compared with protected Forests which was likely explained by the persistence of forest species in unprotected Forests, coupled with the invasion by nonforest species such as the Yellow Bishop (Euplectes capensis) and Red-collared Widowbird (Euplectes ardens) in to such areas. These birds because of their feeding guild prefer disturbed and open habitats (Mulwa et al., 2012; Coetzee and Chown, 2016). On the other hand, our result is contrary to Daily et al., (2001).

Conclusion: This study shows that the habitat preferred by Bishop species is open lands with abundant seeds. Therefore, farmlands should not only be considered as lost habitats but as a repository for quite a number of avian species and therefore, effective farm practices should be encouraged so as not to constitute a threat to birds and other biodiversity.

Acknowledgement: The Authors hereby acknowledge the A. P. Leventis Ornithological Research Institute, University of Jos who fully funded this work. We appreciate the people of Laminga and Fobur for permitting us into their farmlands during this work. We appreciate Chris Laminga for great assistance in the field.

\section{REFERENCES}

Akogwu, SA; Ihuma, JO; Manu, SA (2012). Survey of abundance and diversity of Avian species in Assop Forest Reserve and surrounding farmlands in Jos, Nigeria. Intern. J. Adv. Biol. Res. 2 (3): 506-514.

Alcock, J (2005). Animal behavior: an evolutionary approach $\left(8^{\text {th }}\right.$ edn). Sunderland: Sinauer Associates.

Atuo, FA; Manu, SA (2013). Territory size and habitat selection of Cinnamon-breasted Rock Bunting Emberiza tahapisi in Nigeria. Ostrich 84 (1): 7178 .

Asefa, A; Davies, AB; Mckechnie, AE; Kinahan, AA; Van Rensburg, BJ (2017). Effects of anthropogenic disturbance on bird diversity in Ethiopian montane forests. The Condor 119: 416430.

Bibby, CJ; Burgess, N D; Hill, DA; Mustoe, SH (2004). Bird census techniques. Academic press, London. Pp. 65-66.

Borrow, N; Demey, R (2013). Birds of Western Africa. London: Christopher Helm. Pp. 448-452. 
Clergeau, P; Savard, G; Mennechez, G; Falardeau, G (1998). Birds abundance and diversity along an urban gradient: A comparative study between two sites on different Continents. The Condor 100 (3): 413-425.

Chettri, N; Deb, DC; Sharma, E; Jackson, R (2005). The relationship between bird communities and habitat: A study along a Trekking Corridor in the Sikkim Himlaya. Mountain Research and Development 25 (3): 235-234.

Clergeau, P; Jokimaki, J; Savard, JPL (2001). Are Urban bird communities influence $\mathrm{d}$ by the bird diversity of adjacent landscape? J. Appl. Ecol. 38 (11): 22-34.

Cody, ML (1985): Habitat selection in birds. Academic Press inc. Pp 4-46.

Coetzee, BWT; Chown, SL (2016). Land -use change promotes avian diversity at the expense of species with unique traits. Ecol. and Evol. 67: 610-762.

Daily, GC; Ehrlich, PR; Sa'nchez-Azofeifa, GA (2001). Countryside biogeography: Use of human-dominated habitats by the avifauna of southern Costa Rica. Ecol. Appl. 11: 1-13.

Fry, CH; Keith, S (2004). The Birds of Africa Vol.vii. Christopher Helm, London. Pp 214-242.

Hulme, MF (2007). The density of birds on farmland in West Africa. Ostrich 78 (2): 315-324.

Mahiga, SN; Webala, P; Mware, MJ; Ndang'ang'a, PK (2019). Influence of land-use type on forest bird community composition in Mount Kenya Forest. Int. J. Ecol. 8:1-8.
Manu, SA. (2002). Effects of Habitat Fragmentation on the Distribution of Forest Birds in South Western Nigeria with particular Reference to Ibadan malimbe and other malimbes. D.phill Thesis, Wolfson College, University of Oxford. Pp 205

Manu, SA; Cresswell, W (2007). Addressing sampling bias in counting forest birds: a West African case study. Ostrich 78: 281-286.

Mulwa, RK; Bohning-Gaese, K; Schleuning, M (2012). High bird species diversity in structurally heterogeneous farmland in western Kenya. Biotropica 44: 801-809.

Munoz-Pedreros, A; Gonzalez-Urrutia, M; EncinaMontoya, F; Norambuena, HV (2018). Effects of vegetation strata and human disturbance on bird diversity in green areas in a city in Southern Chile. Avian Res. 9: 38

Pasinelli, G; Grendelmeir, A; Gerber, M; Arletazz, R (2016). Rodent-avoidance, topography and forest structure, shape and territory selection of a forest bird. Biomed. Central Ecol. 16: 24

Soderstrom, B; Kiena, S; Reid, RS (2003). Intensified agricultural land use and bird conservation in Burkina Fasso. J. Agric. Ecos. Environ. 99 (1):113-124

Yallop, ML; Connell, MJ; Bullock, R (2004). Water birds: Herbivory on a newly created wetland complex: potential implication for site management and habitat creation. Wetland Ecol. Manage. 12: 395-408 